\title{
Role of the $\beta$-adrenergic receptor kinase in myocardial dysfunction after brain death
}

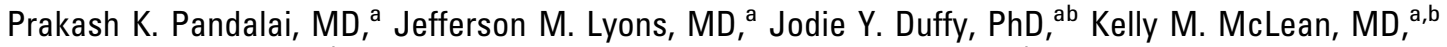 \\ Connie J. Wagner, BS, ${ }^{b}$ Walter H. Merrill, MD, ${ }^{a}$ Jeffrey M. Pearl, MD, ${ }^{a, b}$ and Shahab A. Akhter, MD
}

From the Department of Surgery, Section of Cardiothoracic Surgery, University of Cincinnati College of Medicine, ${ }^{a}$ and Pediatric Cardiothoracic Surgery, Cincinnati Children's Hospital Medical Center, ${ }^{\mathrm{b}}$ Cincinnati, Ohio.

Supported in part by grants 5 T32 HL007382-29 (P.K.P) and P021-040-N366 (K.M.M.) from the National Institutes of Health and a research award from the American Surgical Association Foundation (S.A.A).

Received for publication March 30, 2005; revisions received May 25, 2005; accepted for publication June 16, 2005.

Address for reprints: Shahab A. Akhter, MD, Section of Cardiothoracic Surgery, University of Cincinnati College of Medicine, 231 Albert B. Sabin Way, ML 0558, Cincinnati, OH 46267-0558 (E-mail: shahab. akhter@uc.edu).

J Thorac Cardiovasc Surg 2005;130:1183-9

$0022-5223 / \$ 30.00$

Copyright ( $(2) 2005$ by The American Association for Thoracic Surgery

doi:10.1016/j.jtcvs.2005.06.034
Objective: Significant cardiac dysfunction after brain death leading to exclusion from procurement for cardiac transplantation is seen in up to $25 \%$ of potential organ donors in the absence of structural heart disease. The cause includes uncoupling of the myocardial $\beta$-adrenergic receptor signaling system. The mechanism, however, has not yet been described. This study investigates our hypothesis that brain death causes acute activation of the $\beta$ AR kinase and leads to desensitization of myocardial $\beta$-adrenergic receptors and impaired ventricular function.

Methods: Adult pigs underwent a sham operation or induction of brain death by means of subdural balloon inflation ( $\mathrm{n}=8$ in each group). Cardiac function was assessed by using sonomicrometry at baseline and for 6 hours after the operation. $\beta$-Adrenergic receptor signaling was assessed at 6 hours after the operation by measuring myocardial sarcolemmal membrane adenylate cyclase activity, $\beta$-adrenergic receptor density, $\beta$-adrenergic receptor kinase expression, and activity.

Results: Induction of brain death led to significantly decreased left ventricular systolic and diastolic function. Basal and isoproterenol-stimulated adenylate cyclase activity was blunted in the brain dead group compared with the sham-operated group $(28.3 \pm 4.3 \mathrm{vs}$ $48.3 \pm 7.6 \mathrm{pmol}$ of cyclic adenosine monophosphate $\cdot \mathrm{mg}^{-1} \cdot \mathrm{min}^{-1}[P=.01]$ and 54.8 $\pm 9.6 \mathrm{vs} 114.5 \pm 18 \mathrm{pmol}$ of cyclic adenosine monophosphate $\cdot \mathrm{mg}^{-1} \cdot \min ^{-1}[P<$ $.02])$. There was no difference in $\beta$-adrenergic receptor density between the brain dead and sham-operated groups. Myocardial $\beta$-adrenergic receptor kinase expression was 3 -fold greater in the brain dead versus sham-operated groups, and membrane $\beta$-adrenergic receptor kinase activity was 2.5 -fold greater in the brain dead group compared with that seen in the sham-operated group.

Conclusion: Induction of brain death leads to significant left ventricular dysfunction in this porcine model. Cardiac $\beta$-adrenergic receptors are clearly uncoupled after brain death, and our data suggest that the mechanism is acute increase of myocardial $\beta$-adrenergic receptor kinase activity, leading to $\beta$-adrenergic receptor desensitization and ventricular dysfunction.

$\mathrm{T}$ he incidence of heart failure (HF) continues to increase in the United States and worldwide. Despite advances in medical therapy, the average survival for patients given a diagnosis of $\mathrm{HF}$ is only approximately 5 years. The most effective long-term therapy for end-stage HF is cardiac transplantation. Despite the excellent outcomes after transplantation, this remains an extremely limited option because of the donor organ shortage. Adding to the problem, nearly $25 \%$ of potential heart donors without evidence of structural heart disease are found to have significantly decreased myocardial function and therefore are not considered for procurement. The cause of ventricular dysfunction after brain death (BD) is likely multifactorial, and previously reported hypotheses include ischemic injury, direct catecholamine-induced myocardial injury, and impaired $\beta$-adrenergic receptor ( $\beta \mathrm{AR}$ ) signaling. Although uncoupling of 


$$
\begin{aligned}
& \text { Abbreviations and Acronyms } \\
& \begin{aligned}
\text { AC } & =\text { adenylate cyclase } \\
\text { ANOVA } & =\text { analysis of variance } \\
\text { ATP } & =\text { adenosine triphosphate } \\
\text { BD } & =\text { brain death } \\
\text { cAMP } & =\text { cyclic adenosine monophosphate } \\
\text { GRK } & =\text { G protein-coupled receptor kinases } \\
\text { HF } & =\text { heart failure } \\
\text { LV } & =\text { left ventricular } \\
\text { PRSW } & =\text { preload recruitable stroke work }
\end{aligned}
\end{aligned}
$$

$\beta$ ARs has been described in human donor heart dysfunction, the mechanism underlying the impairment of this critical signaling system has not. G protein-coupled receptor kinases (GRKs) are serine-threonine kinases that phosphorylate agonist-occupied $G$ protein-coupled receptors and lead to receptor desensitization. GRK2 or $\beta$ AR kinase 1 ( $\beta$ ARK1) is abundantly expressed in the heart and plays an important role in regulating $\beta \mathrm{AR}$ signaling and cardiac function. We hypothesize that the catecholamine surge resulting from BD leads to activation of myocardial $\beta$ ARs and subsequent activation of $\beta$ ARK1. This leads to desensitization of myocardial $\beta$ ARs and decreased ventricular function. In this study we used a validated porcine model of $\mathrm{BD}$ and ventricular dysfunction to determine the mechanism of $\beta A R$ uncoupling. Inhibition of myocardial $\beta$ AR desensitization in this clinical setting might lead to an expanded donor organ population.

\section{Materials and Methods \\ Induction of BD}

All animals received humane care in compliance with the "Principles of laboratory animal care" formulated by the National Society for Medical Research and the "Guide for the care and use of laboratory animals" prepared by the Institute of Laboratory Animals Resources and published by the National Institutes of Health (National Institutes of Health publication no. 86-23, revised 1985). The Animal Care and Use Committee at Children's Hospital Research Foundation also approved the protocol.

Crossbred adolescent pigs $(20-35 \mathrm{~kg})$ were anesthetized with ketamine ( $20 \mathrm{mg} / \mathrm{kg}$ administered intramuscularly) and acepromazine $(1.1 \mathrm{mg} / \mathrm{kg}$ administered intramuscularly), intubated, and ventilated. Deep sedation and paralysis were maintained with an infusion of sodium pentobarbital $\left(20 \mathrm{mg} \cdot \mathrm{kg}^{-1} \cdot \mathrm{h}^{-1}\right)$, intermittent fentanyl $\left(10 \mu \mathrm{g} \cdot \mathrm{kg}^{-1} \cdot \mathrm{h}^{-1}\right)$, and intermittent pancuronium (200 $\mu \mathrm{g} \cdot \mathrm{kg}^{-1} \cdot \mathrm{h}^{-1}$ ). A 22F Fogarty occlusion catheter (Baxter, Irvine, Calif) and an open lumen pressure catheter (Medtronic, Minneapolis, Minn) were placed into the subdural space through a frontoparietal burr hole. A LaserFlo laser Doppler blood perfusion monitor (Vasamedics, St Paul, Minn) was inserted directly into the brain. By using percutaneous electrodes, a 5-lead electroencephalography monitor was placed. Through a median sternotomy, piezoelectric ultrasound crystals (Sonometrics, London, Ontario, Canada) were placed in 3 axes on the heart to monitor cardiac function. Pressure transducer-tipped $2 \mathrm{~F}$ or $3 \mathrm{~F}$ catheters (Millar
Instruments Inc, Houston, Tex) were placed in both ventricles and the pulmonary artery. The subdural balloon was then inflated with $25 \mathrm{~mL}$ of water over 1 minute to induce BD, which was confirmed by means of electroencephalography and correlated with changes in laser-detected blood flow. Cardiopulmonary function and intracranial pressure were monitored continuously throughout the experiment. Arterial blood gas, electrolytes, and $\mathrm{pH}$ were checked, and blood samples were collected at baseline; 0, 2, 4, 6, 10, 15, 30, and 60 minutes after BD; and then hourly for 6 hours (Bayer Diagnostics, East Walpole, Mass). Left ventricular (LV) enddiastolic volume was kept constant. After 6 hours of BD and observation, the animals were killed with sodium pentobarbital, and myocardial specimens were obtained.

\section{Analysis of Cardiac Function}

The Cardiosoft data analysis software (Sonometrics) determined the derivative of the change in pressure over time and pressure-volume relationships. Preload recruitable stroke work (PRSW) was calculated from data collected during transient inferior vena caval occlusion. ${ }^{1}$

\section{Protein Immunoblotting}

Tissue was homogenized in ice-cold lysis buffer $(25 \mathrm{mmol} / \mathrm{L}$ Tris- $\mathrm{HCl}$ [pH 7.5], $5 \mathrm{mmol} / \mathrm{L}$ ethylenediamine tetraacetic acid, 5 $\mathrm{mmol} / \mathrm{L}$ ethyleneglycol-bis-( $\beta$-aminoethylether)-N,N,N $\mathrm{N}^{\prime}, \mathrm{N}^{\prime}$-tetraacetic acid, $10 \mu \mathrm{g} / \mathrm{mL}$ leupeptin, $20 \mu \mathrm{g} / \mathrm{mL}$ aprotinin, and 1 $\mathrm{mmol} / \mathrm{L}$ phenylmethylsulfonyl fluoride). Nuclei and tissue were separated by means of centrifugation at $800 \mathrm{~g}$ for 20 minutes. The crude supernatant was then centrifuged at $20,000 \mathrm{~g}$ for 20 minutes. Protein concentrations were determined on the supernatant (cytosolic fraction). Sedimented proteins (membrane fraction) were resuspended in $50 \mathrm{mmol} / \mathrm{L}$ HEPES $(\mathrm{pH} 7.3)$ and $5 \mathrm{mmol} / \mathrm{L} \mathrm{MgCl}_{2}$. The immunodetection of myocardial levels of $\beta$ ARK1 (GRK2, polyclonal rabbit IgG; Santa Cruz Biotechnology, Inc, Santa Cruz, Calif) was performed on an equal amount of protein from cytosolic and membrane extracts $(80 \mu \mathrm{g})$ electrophoresed through $12 \%$ Tris-glycine gels and transferred to nitrocellulose. Membranes were blocked in 5\% nonfat dried milk in $0.1 \%$ Tween 20 in phosphate-buffered saline for 1 hour at room temperature. The protein was visualized with a horseradish peroxidase-linked secondary antibody and ECL detection (Amersham, Piscataway, NJ).

\section{GRK Activity by Rhodopsin Phosphorylation}

The membrane fractions of the myocardial extracts were used to determine GRK activity. Extracts (100 $\mu \mathrm{g}$ of protein) were incubated with rhodopsin-enriched rod outer-segment membranes in reaction buffer containing the following: $\mathrm{MgCl}_{2}, 10 \mathrm{mmol} / \mathrm{L}$; Tris- $\mathrm{HCl}, 20$ $\mathrm{mmol} / \mathrm{L}$; ethylenediamine tetraacetic acid, $2 \mathrm{mmol} / \mathrm{L}$; ethyleneglycolbis-( $\beta$-aminoethylether)-N,N,N'， $\mathrm{N}^{\prime}$-tetraacetic acid, $5 \mathrm{mmol} / \mathrm{L}$; and adenosine triphosphate [ATP], $0.1 \mathrm{mmol} / \mathrm{L}$ (containing $\left.\left[\gamma_{-}{ }^{32} \mathrm{P}\right] \mathrm{ATP}\right)$, as previously described. ${ }^{2}$ After incubating in white light for 15 minutes at room temperature, reactions were quenched with ice-cold lysis buffer and centrifuged for 15 minutes at $13,000 g$. Sedimented proteins were resuspended in $25 \mu \mathrm{L}$ of protein gel loading dye and treated with $12 \%$ sodium dodecylsulfate-polyacrylamide gel electrophoresis. Phosphorylated rhodopsin was visualized by using autoradiography of dried polyacrylamide gels and quantified with a Molecular Dynamics PhosphorImager. 


\section{Radioligand Binding}

Total $\beta$ AR density was determined by incubating $25 \mu \mathrm{g}$ of cardiac sarcolemmal membranes with a saturating concentration of $\left[{ }^{125} \mathrm{I}\right]-$ labeled cyanopindolol and $20 \mu \mathrm{mol} / \mathrm{L}$ alprenolol to define nonspecific binding. Sarcolemmal membrane samples from brain dead and control animals were done in triplicate with $300 \mathrm{pmol} / \mathrm{L}$ of $\left[{ }^{125} \mathrm{I}\right]$-labeled cyanopindolol in $250 \mu \mathrm{L}$ of binding buffer $(50$ $\mathrm{mmol} / \mathrm{L}$ HEPES [pH 7.3], $5 \mathrm{mmol} / \mathrm{L} \mathrm{MgCl}_{2}$, and $0.1 \mathrm{mmol} / \mathrm{L}$ ascorbic acid). Assays were done at $37^{\circ} \mathrm{C}$ for 1 hour and then filtered over GF/C glass fiber filters (Whatman, Middlesex, United Kingdom) that were washed twice and counted in a gamma counter. Data were analyzed by using nonlinear least-square curve fit (GraphPad Prism; GraphPad, San Diego, Calif).

\section{Adenylyl Cyclase Activity}

Cardiac sarcolemmal membranes (20 $\mu \mathrm{g}$ of protein) were incubated for 15 minutes at $37^{\circ} \mathrm{C}$ with $\left[\alpha{ }^{32} \mathrm{P}\right]$ ATP under basal conditions, $10^{-4} \mathrm{~mol} / \mathrm{L}$ isoproterenol, or $10 \mathrm{mmol} / \mathrm{L}$ sodium fluoride. Cyclic adenosine monophosphate (cAMP) production was quantified by using standard methods described previously. ${ }^{3}$

\section{Statistical Analysis}

Repeated-measures analysis of variance (ANOVA) was used to analyze serial data over time within treatment groups. Analyses were conducted with Statview 4.01 software (Abacus Concepts Inc, Berkley, Calif). Experimental groups were compared by using the Student $t$ test or 1-way ANOVA, as appropriate. The Bonferroni test was applied to all significant ANOVA results by using SigmaStat software (Systat Software, Point Richmond, Calif). $P$ values of less than .05 were considered statistically significant. All results are expressed as means \pm SEM.

\section{Results}

\section{In Vivo Cardiac Physiology}

Induction of $\mathrm{BD}$ was performed by means of subdural inflation of a Fogarty balloon, and BD itself was observed on the basis of electroencephalographic changes and the consequent hemodynamic instability characterized by the Cushing reflex. PRSW, a load-independent measure of ventricular function, was measured during transient vena caval occlusion at the above-mentioned time points. At baseline, both brain dead and sham-operated animals had similar PRSW values $(43.3 \pm 3.1$ vs $47.5 \pm 4.6$; Figure $1, A)$. In contrast, PRSW was significantly decreased 6 hours after BD compared with that seen in sham-operated animals $(21.4$ \pm 3.3 vs $36.9 \pm 3.4, P<.02$; Figure $1, A)$, indicating marked decrease in LV function after BD. Consistent with these findings, there was a significant decrease in LV PRSW 6 hours after BD compared with the baseline function for this group $(21.4 \pm 3.4$ vs $43.3 \pm 3.1, P<.01)$. Similarly, $\mathrm{LV} \mathrm{dP/dT} \mathrm{min}_{\text {min }}$ a measure of diastolic function, was significantly impaired 6 hours after BD compared with that seen in sham-operated animals $(-250 \pm 38$ vs $-541 \pm 31 \mathrm{~mm}$ $\mathrm{Hg} / \mathrm{s}, P<.02$; Figure $1, B)$. These indices of both systolic and diastolic function indicate impaired myocardial contrac-

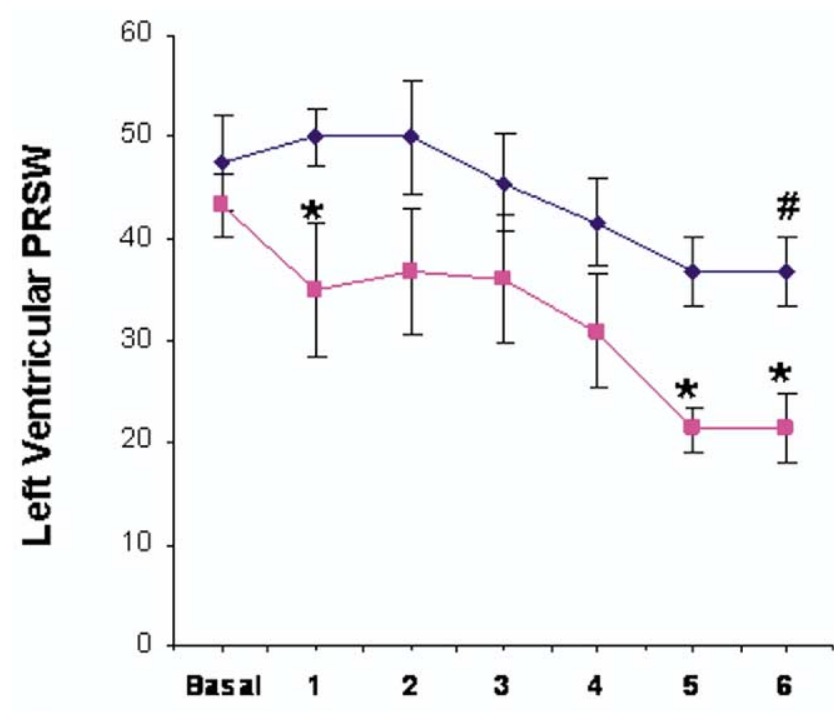

A Hours post Brain Death

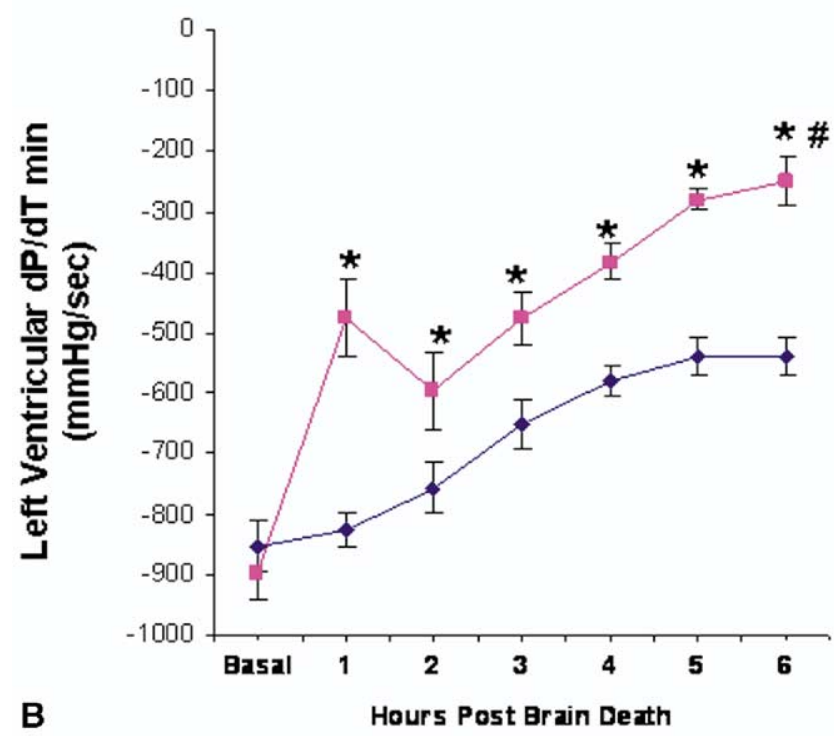

Figure 1. A, Left ventricular preload recruitable stroke work (PRSW) at baseline and after sham operation or induction of brain death. ${ }^{*} \boldsymbol{P}<.05$ versus sham operation and baseline drain death. $\# \boldsymbol{P}=$ not significant versus baseline sham operation. Diamonds, Sham operation ( $n=8$ ); squares, BD $(n=8)$. B, Left ventricular $\mathrm{dP} / \mathrm{dT}_{\min }$ at baseline and after sham operation or induction of $\mathrm{BD}$. ${ }^{*} \boldsymbol{P}<.05$ versus sham operation. \#P $<.05$ versus baseline BD. Diamonds, Sham operation $(n=8)$; squares, BD $(n=8)$.

tility after BD and are consistent with previously described animal models. ${ }^{4,5}$

\section{Myocardial $\boldsymbol{\beta A R}$ Signaling}

We assessed receptor-effector coupling in sarcolemmal membranes from hearts of brain dead and sham-operated 


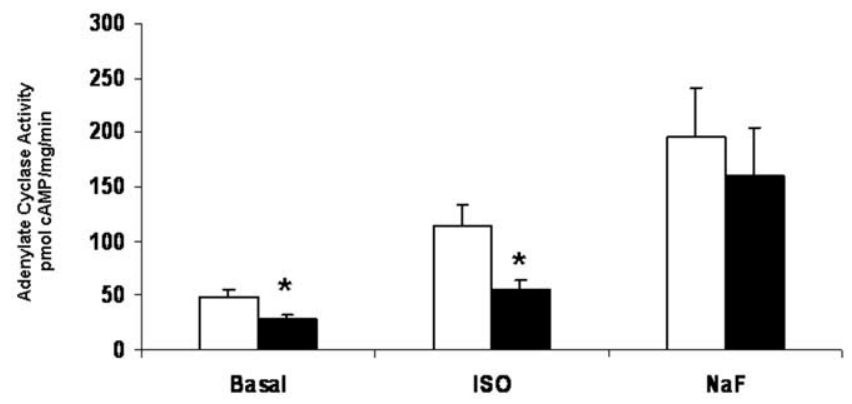

Figure 2. Myocardial sarcolemmal membrane adenylate cyclase activity 6 hours after sham operation or induction of BD. ISO, 10-4 $\mathrm{mol} / \mathrm{L}$ isoproterenol; $\mathrm{NaF}, 50 \mathrm{mmol} / \mathrm{L}$ sodium fluoride. Open columns, Sham operation ( $n=8)$; filled columns, BD $(n=8)$. ${ }^{*} P<$ .03 versus sham operation. $C A M P$, Cyclic adenosine monophosphate.

animals by measuring adenylate cyclase (AC) activity to examine the biochemical effects of BD on the myocardial $\beta$ AR signaling cascade. Basal AC activity was diminished in the BD group compared with sham-operated animals $\left(28.3 \pm 4.3\right.$ vs $48.3 \pm 7.6 \mathrm{pmol}$ of $\mathrm{cAMP} \cdot \mathrm{mg}^{-1} \cdot \mathrm{min}^{-1}, P$ $<.01$; Figure 2). Isoproterenol-stimulated AC activity was also significantly blunted in the BD group $(54.8 \pm 9.6$ vs $114.5 \pm 18.8 \mathrm{pmol}$ of $\mathrm{cAMP} \cdot \mathrm{mg}^{-1} \cdot \mathrm{min}^{-1}, P<.02$; Figure 2). AC activity stimulated by sodium fluoride, which induces maximal stimulation of the $\mathrm{G}_{\alpha \mathrm{s}}$ protein, was similar in both the BD and sham-operated groups $(160.3 \pm 43$ vs $196 \pm 45.2 \mathrm{pmol} / \mathrm{mg} / \mathrm{min}$; Figure 2). This blunting of basal and agonist-stimulated AC activity suggests that uncoupling of myocardial $\beta$ ARs occurs within 6 hours of BD. Furthermore, there was no significant difference in the maximal stimulation achieved with sodium fluoride between groups,

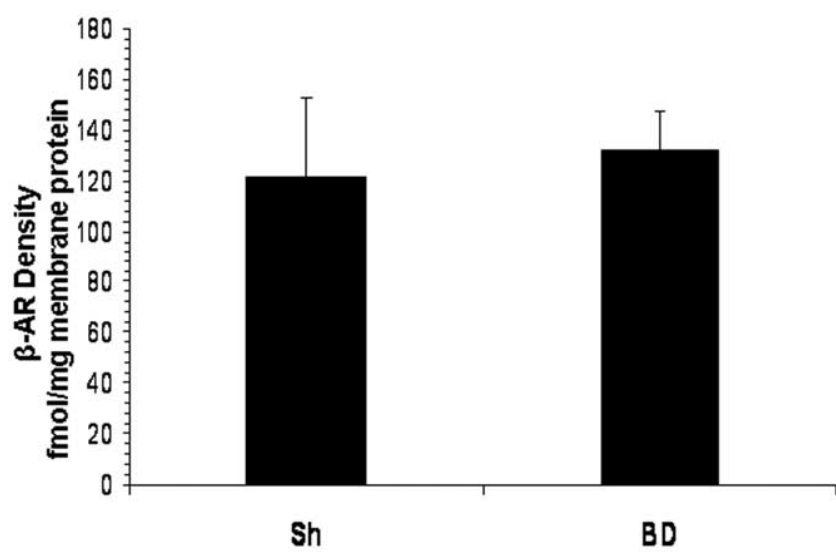

Figure 3. Myocardial sarcolemmal membrane $\beta$-adrenergic receptor $(\beta A R)$ density at 6 hours after sham operation (Sh) or induction of brain death ( $B D ; n=8$ in each group performed in triplicate). $P=$ not significant between groups.

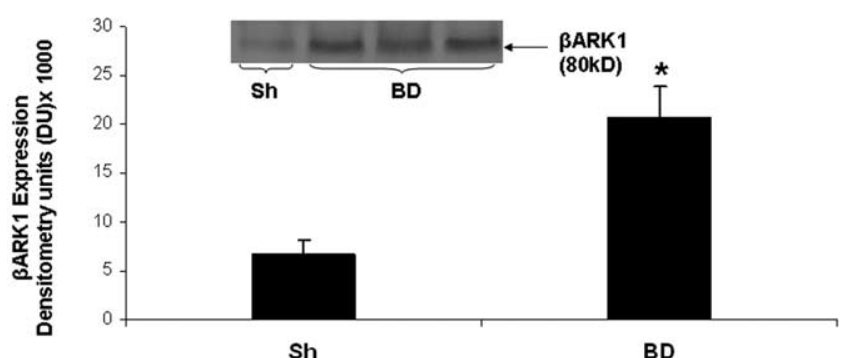

Figure 4. Myocardial sarcolemmal membrane $\beta$-adrenergic receptor kinase ( $\beta A R K 1)$ protein expression at 6 hours after sham operation $(S h)$ or induction of brain death $(B D ; n=8$ in each group). ${ }^{*} \boldsymbol{P}<.05$ versus sham operation.

suggesting that the AC effector itself is intact in both brain dead and sham-operated animals and that uncoupling is occurring at the receptor- $\mathrm{G}$ protein level.

Myocardial $\beta A R$ Density and G Protein Expression

Total myocardial sarcolemmal membrane $\beta$ AR density was measured 6 hours after induction of BD, and there was no difference between the $\mathrm{BD}$ and sham-operated groups $(121.5 \pm 31$ vs $132.15 \pm 14.7 \mathrm{fmol} / \mathrm{mg}$; Figure 3$)$. Protein immunoblotting was performed to determine whether any differences were present between groups in $G$ protein expression. There was no difference between groups in $G_{\alpha \mathrm{s}}$ or $\mathrm{G}_{\alpha \mathrm{i}}$ expression (data not shown). This suggests that the $\beta \mathrm{AR}$ uncoupling is not due to altered expression of either $\mathrm{G}_{\alpha \mathrm{s}}$ or $\mathrm{G}_{\alpha \mathrm{i}}$, which stimulate or inhibit AC activity, respectively.

\section{Myocardial GRK Expression and Activity}

Myocardial $\beta$ ARK1 expression in the membrane fraction 6 hours after BD was enhanced compared with that seen in the sham-operated group $(20.7 \pm 3.2$ vs $6.7 \pm 1.5$ densitometry units, $P<.05$; Figure 4 ). There was no difference between groups in total myocardial $\beta A R K 1$ expression (data not shown). The increase in $\beta$ ARK1 expression in the membrane fraction after BD was also consistent with an increase in myocardial membrane GRK activity, as measured by using rhodopsin phosphorylation (20.8 \pm 1.0 [BD group] vs $8.9 \pm 0.85$ [sham-operated group] densitometry units, $P<$ .02; Figure 5). We also examined LV myocardial membrane expression of GRK5, the other GRK in the heart, by means of protein immunoblotting and found no difference between the $\mathrm{BD}$ and sham-operated groups (data not shown). The relative expression of GRK5 was very low compared with $\beta A R K 1$ in myocardial membrane fractions.

\section{Discussion}

Cardiac transplantation remains the best long-term treatment for patients with end-stage HF. Unfortunately, it remains an epidemiologically trivial therapy for this disease 
because the number of organs available for donation is extremely limited. Each year in the United States alone, only approximately half of the patients on the waiting list undergo heart transplantation, and patient criteria for listing are very strict because of the critical donor limitations. ${ }^{6}$ Adding to the problem of a limited number of potential organ donors is donor heart dysfunction. Up to $25 \%$ of potential heart donors are found to have severely decreased cardiac function after BD in the absence of structural or ischemic heart disease. ${ }^{7}$ Because of the morbidity and mortality associated with early graft dysfunction and with questionable recovery of ventricular function, these organs are seldom used. The cause of donor heart dysfunction is likely multifactorial and might include ischemic injury, ${ }^{8}$ increased free radical formation, direct catecholamine-induced myocardial injury, and impaired $\beta \mathrm{AR}$ signaling, ${ }^{9,10}$ resulting in ventricular dysfunction after BD. Desensitization of the $\beta A R$ signaling system has been reported in human donor heart dysfunction ${ }^{9}$ and animal models of $\mathrm{BD},{ }^{10}$ but the mechanism underlying this defect has not been described. This is the first report that comprehensively investigates multiple levels of the $\beta A R$ signaling system in a model of BD with ventricular dysfunction. In this study we demonstrate that there is significant desensitization and uncoupling of myocardial $\beta A R$ after $\mathrm{BD}$ as a result of an acute increase in the activity of $\beta$ ARK1, which is a critical modulator of $\beta \mathrm{AR}$ signaling and cardiac function.

The myocardial $\beta$ AR signaling pathway plays a critical role in the regulation of cardiac contractility. $\beta$ ARs are the primary myocardial targets of the sympathetic neurotransmitter norepinephrine and the adrenal hormone epinephrine. Activation of $\beta$ ARs in the heart by these 2 catecholamines leads to positive chronotropic and inotropic action through stimulation of adenylyl cyclase and subsequent increases in cAMP and intracellular $\mathrm{Ca}^{2+}$ release. ${ }^{11}$ Continued exposure of $\beta$ ARs to agonists results in a rapid decrease in responsiveness, which is known as desensitization. ${ }^{12}$ Agonistdependent desensitization can be initiated by the phosphorylation of activated receptors by members of the family of GRKs. ${ }^{13}$ The $\beta$ AR kinase 1 ( $\beta$ ARK1 or GRK2) is a GRK that specifically phosphorylates activated $\beta_{1^{-}}$and $\beta_{2}$-ARs, leading to desensitization in vitro and in vivo. It is becoming increasingly more evident that $\beta$ ARK1 plays a critical role in myocardial function. Alteration of myocardial $\beta$ ARK1 activity can have profound effects on in vivo cardiac performance. Recent studies have described decreased cardiac contractility in transgenic mice with cardiac-specific overexpression of $\beta$ ARK $1^{14}$ and restoration of or enhanced $\beta A R$ signaling and cardiac function resulting from inhibition of increased myocardial $\beta$ ARK1 both in vitro ${ }^{15,16}$ and in vivo. ${ }^{14,17-19}$

Decreased myocardial function after BD leading to exclusion from procurement is not an uncommon clinical

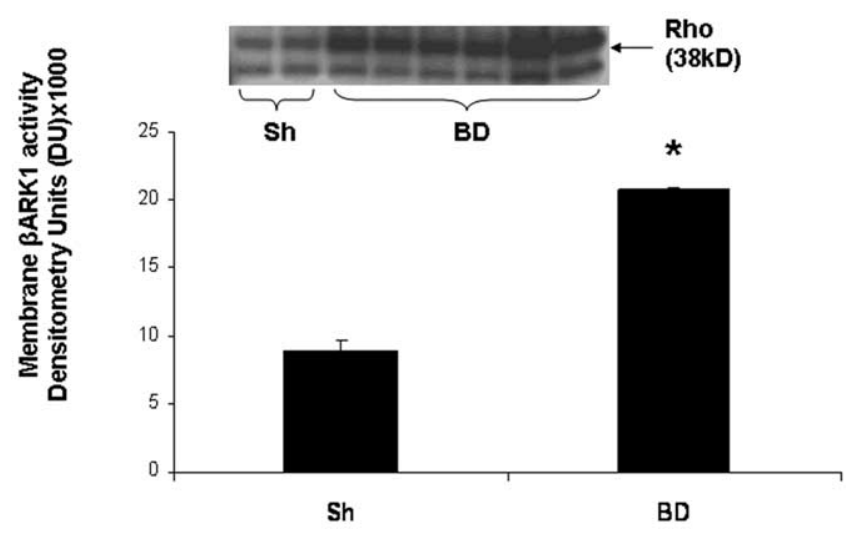

Figure 5. Myocardial sarcolemmal membrane $\mathbf{G}$ protein-coupled receptor kinase activity at 6 hours after sham operation (Sh) or induction of brain death ( $B D ; n=8$ in each group). ${ }^{*} P<.02$ versus sham operation.

situation. There is a well-described catecholamine surge associated with the induction of $\mathrm{BD}$, which leads to an initial hypertensive and tachycardic state. In an animal model of BD, circulating dopamine, epinephrine, and norepinephrine concentrations were increased by $800 \%, 700 \%$, and $100 \%$ respectively. ${ }^{20}$ These levels are similar to those seen in the clinical situation. ${ }^{21}$ A study of human hearts with significant donor heart dysfunction established that $\beta A R$ desensitization and uncoupling was present after BD, as demonstrated by diminished response to $\beta$-agonist stimulation and blunted agonist-stimulated AC activity. ${ }^{9}$ This indicated that $\beta \mathrm{AR}$ desensitization might play an important role in donor heart dysfunction.

We sought to define the mechanism of $\beta$ AR uncoupling and myocardial dysfunction after BD. In the present study we used a valid and reproducible porcine model of $\mathrm{BD}{ }^{4}$ With constant loading conditions, LV systolic and diastolic function were significantly decreased at 6 hours after induction of BD compared with that seen in sham-operated control animals. Six hours after BD, we studied myocardial $\beta A R$ signaling at multiple levels to determine whether desensitization was contributing to ventricular dysfunction in the BD group. Basal and isoproterenol-stimulated myocardial sarcolemmal membrane AC activity was blunted in the $\mathrm{BD}$ group compared with that seen in the sham-operated control animals. This finding clearly indicates significant functional uncoupling, or desensitization, of $\beta$ ARs after BD in this model. Ligand binding was performed on myocardial membrane preparations to determine whether downregulation of $\beta$ ARs was present to account for the decrease in AC activity. We found no difference in total $\beta A R$ density between the $\mathrm{BD}$ and sham groups, indicating that $\beta \mathrm{AR}$ downregulation was not present. Expression of the ACstimulatory $\mathrm{G}$ protein subunit $\mathrm{G}_{\alpha \mathrm{s}}$ and the inhibitory subunit 
$\mathrm{G}_{\alpha \mathrm{i}}$ was assessed by means of protein immunoblotting, and no differences between groups was present. A decrease in $\mathrm{G}_{\alpha \mathrm{s}}$ or an increase in $\mathrm{G}_{\alpha \mathrm{i}}$ expression could also lead to impaired AC activation by $\beta$ ARs. ${ }^{22}$ Because $\beta$ ARK 1 translocation from the cytosolic fraction to the membrane fraction is necessary for targeting $\beta$ ARs, we assessed myocardial membrane $\beta$ ARK1 expression by means of immunoblotting and found a 3-fold increase in the BD group versus the control group. Total myocardial $\beta$ ARK1 expression was not different between groups. Rhodopsin phosphorylation assays were performed on membrane preparations to specifically assess myocardial GRK activity, and there was a 2.5 -fold increase in membrane GRK activity after BD compared with that seen in sham-operated control hearts. We conclude from these data that enhanced myocardial $\beta$ ARK1 activity is the primary mechanism responsible for acute $\beta A R$ desensitization present after BD.

Modulation of cardiac $\beta$ ARK1 activity with the goal of restoration of $\beta A R$ signaling and ventricular function has been reported by our laboratory and others using novel experimental approaches. ${ }^{16,17,23}$ Inhibition of myocardial $\beta$ ARK1 activity could be a useful strategy to increase the number of potential cardiac donors suitable for procurement and transplantation. The acute increase in circulating catecholamines and stimulation of myocardial $\beta$ ARs that accompanies BD appears to lead to activation of $\beta$ ARK1 with subsequent receptor uncoupling. The degree to which $\beta \mathrm{AR}$ signaling is impaired and the subsequent effect on cardiac function is clearly variable between potential organ donors and also depends on baseline cardiac function. Several reports have described inhibition of myocardial $\beta A R K 1$ activity by using a protein derived from the $\mathrm{COOH}$ terminus region of $\beta$ ARK1 ( $\beta$ ARKct). ${ }^{24}$ By using transgenic models or gene therapy, inhibition of $\beta$ ARK1 activity in the heart enhances $\beta A R$ coupling and ventricular function, particularly in the setting of experimental chronic HF. ${ }^{16,17,23}$ In addition, we have previously reported on $\beta$-adrenergic-based gene therapy to the transplanted heart ex vivo to increase cardiac $\beta_{2}$-AR density by using adenoviral-mediated transgene delivery. ${ }^{25}$ Even more relevant to our study, use of an adenoviral vector to deliver the $\beta$ ARKct transgene to the rabbit heart ex vivo led to improved ventricular function in the allograft after transplantation. ${ }^{26}$ The initial sympathetic hyperactivity might be attenuated to some degree with the use of a short-acting $\beta$-blocker, such as esmolol. One effect and potential therapeutic mechanism of chronic $\beta$-blockade is attenuation of myocardial $\beta$ ARK1 activity. ${ }^{27}$ However, the acute effect of this therapy on GRK activity has not been studied. It is likely that a pharmaceutical inhibitor of $\beta$ ARK1 activity might someday become available that could have a large effect on the medical therapy of chronic HF. In addition, this strategy might be very useful to prevent $\beta A R$ desensitization and potential cardiac dysfunction in the setting of BD.

This is the first report to describe enhanced $\beta$ ARK1 activity as the mechanism of $\beta$ AR uncoupling and associated myocardial dysfunction after BD. Future studies to investigate the potentially beneficial effects of acute $\beta$ ARK1 inhibition appear warranted.

\section{References}

1. Glower DD, Spratt JA, Snow ND, Kabas JS, Davis JW, Olsen CO, et al. Linearity of the Frank-Starling relationship in the intact heart: the concept of preload recruitable stroke work. Circulation. 1985;5:994-1009.

2. Akhter SA, Milano CA, Shotwell KF, Cho MC, Rockman HA, Lefkowitz RJ, et al. Transgenic mice with cardiac overexpression of $\alpha_{1 \mathrm{~B}}$-adrenergic receptors. J Biol Chem. 1997;272:21253-9.

3. Salomon Y, Londos C, Rodbell M. A highly sensitive adenylate cyclase assay. Anal Biochem. 1974;58:541-8.

4. Mertes PM, Abassi KE, Jaboin Y, Burtin P, Pinelli G, Carteaux JP, et al. Changes in hemodynamic and metabolic parameters following induced brain death in the pig. Transplantation. 1994;58:414-8.

5. Bittner HB, Kendall SWH, Campbell KA, Montine TJ, VanTrigt P. A valid experimental brain death organ donor model. J Heart Lung Transplant. 1995;14:308-17.

6. Bennett LE, Keck BM, Hertz MI, Trulock EP, Taylor DO. Worldwide thoracic organ transplantation: a report from the UNOS/ISHLT international registry for thoracic organ transplantation. Clin Transpl. 2001;25-40.

7. Miniati DN, Robbins RC. Heart transplantation: a thirty-year perspective. Annu Rev Med. 2002;53:189-205.

8. Halejcio-Delophont P, Siaghy EM, Devaux Y, Richoux JP, Bischoff $\mathrm{N}$, Carteaux JP, et al. Consequences of brain death on coronary blood flow and myocardial metabolism. Transplant Proc. 1998;30:2840-1.

9. White M, Wiechmann RJ, Roden RL, Hagan MB, Wollmering MM, Port $\mathrm{JD}$, et al. Cardiac $\beta$-adrenergic neuroeffector systems in acute myocardial dysfunction related to brain injury. Circulation. 1995;92:2183-9.

10. D'Amico TA, Meyers CH, Koutlas TC, Peterseim DS, Sabiston DC, Van Trigt $\mathrm{P}$, et al. Desensitization of myocardial $\beta$-adrenergic receptors and deterioration of left ventricular function after brain death. J Thorac Cardiovasc Surg. 1995;110:746-51.

11. Brodde OE. $\beta$-Adrenergic receptors in failing human myocardium. Basic Res Cardiol. 1993;91:35-40.

12. Freedman NJ, Liggett SB, Drachman DE, Pei G, Caron MG, Lefkowitz RJ. Phosphorylation and desensitization of the human $\beta$-adrenergic receptor: involvement of $\mathrm{G}$ protein-coupled receptor kinases and cAMP-dependant protein kinase. J Biol Chem. 1995;270:17953-61.

13. Inglese J, Freedman NJ, Koch WJ, Lefkowitz RJ. Structure and mechanism of the G protein-coupled receptor kinases. J Biol Chem. 1993; 268:23735-8.

14. Koch WJ, Rockman HA, Samama P, Hamilton R, Bond RA, Milano $\mathrm{CA}$, et al. Cardiac function in mice overexpressing the $\beta$-adrenergic receptor kinase or a $\beta$ ARK inhibitor. Science. 1995;268:1350-3.

15. Drazner MH, Peppel KC, Dyer S, Grant AO, Koch WJ, Lefkowitz RJ. Potentiation of beta-adrenergic signaling by adenoviral-mediated gene transfer in adult rabbit ventricular myocytes. J Clin Invest. 1997;99: 288-96.

16. Akhter, SA, Skaer CA, Kypson AP, McDonald PH, Peppel KC, Glower DD, et al. Restoration of $\beta$-adrenergic signaling in failing cardiac ventricular myocytes via adenoviral-mediated gene transfer. Proc Natl Acad Sci U S A. 1997;94:12100-5.

17. Akhter SA, Eckhart AD, Rockman HA, Shotwell K, Lefkowitz RJ, Koch WJ. In vivo inhibition of elevated myocardial $\beta$-adrenergic receptor kinase activity in hybrid transgenic mice restores normal $\beta$-adrenergic signaling and function. Circulation. 1999;100:648-53.

18. Shah AS, White DC, Emani S, Kypson AP, Lilly RE, Wilson K, et al. In vivo ventricular gene delivery of a beta-adrenergic receptor kinase inhibitor to the failing heart reverses cardiac dysfunction. Circulation. 2001;103:1311-6. 
19. White DC, Hata JA, Shah AS, Glower DD, Lefkowitz RJ, Koch WJ. Preservation of myocardial beta-adrenergic receptor signaling delays the development of heart failure after myocardial infarction. Proc Natl Acad Sci U S A. 2000;97:5428-33.

20. Chen EP, Bittner HB, Kendall SW, VanTrigt P. Hormonal and hemodynamic changes in a validated model of brain death. Crit Care Med. 1996;24:1352-9.

21. Power DJ, Hendricj A, Nyhuis A, Strate R. Changes in serum catecholamine levels in patients who are brain dead. J Heart Lung Transplant. 1992;11:1046-53.

22. Robishaw JD, Foster KA. Role of G proteins in the regulation of the cardiovascular system. Апnи Rev Physiol. 1989;51:229-44.

23. Lefkowitz RJ, Rockman HA, Koch WJ. Catecholamines, cardiac $\beta$-adrenergic receptors, and heart failure. Circulation. 2000;101:1634-7.
24. Koch WJ, Inglese J, Stone WC, Lefkowitz RJ. The binding site for the beta gamma subunits of heterotrimeric $\mathrm{G}$ proteins on the $\beta$-adrenergic receptor kinase. J Biol Chem. 1993;268:8256-60.

25. Kypson AP, Peppel K, Akhter SA, Lilly ER, Glower DD, Lefkowitz, et al. Ex vivo adenoviral-mediated gene transfer to the adult rat heart. J Thorac Cardiovasc Surg 1998;115:623-30.

26. Tevaearai HT, Walton GB, Eckhart AD, Keys JR, Koch WJ. Donor heart contractile dysfunction following prolonged ex vivo preservation can be prevented by gene-mediated $\beta$-adrenergic signaling modulation. Eur J Cardiothorac Surg. 2002;22:733-7.

27. Iaccarino G, Tomhave ED, Lefkowitz RJ, Koch WJ. Reciprocal in vivo regulation of myocardial $G$ protein-coupled receptor kinase expression by $\beta$-adrenergic receptor stimulation and blockade. Circulation. 1998;98:1783-9.

\section{Online-www.aats.org}

Now you can get The Journal of Thoracic and Cardiovascular Surgery online. The Journal online brings you faster delivery time, easy searching of current and back issues, links to PubMed, AATS, WTSA, and other important sites, and more. Visit the Journal online today.

\section{Receive tables of contents by e-mail}

To receive the tables of contents by e-mail, sign up through our Web site at http://www.mosby.com/jtcvs

Choose E-mail Notification

Simply type your e-mail address in the box and click the Subscribe button.

Alternatively, you may send an e-mail message to majordomo@mosby.com.

Leave the subject line blank and type the following as the body of your message: subscribe jtcvs_toc

You will receive an e-mail to confirm that you have been added to the mailing

list.

Note that TOC e-mails will be sent out when a new issue is posted to the Web site. 